\title{
DAKWAH ISLAM DENGAN PENDEKATAN BIMBINGAN DAN KONSELING
}

\author{
Siti Prihatiningtyas \\ Fakultas Dakwah dan Komunikasi UIN Walisongo \\ Email: siti.prihatiningtyas@walisongo.ac.id
}

\begin{abstract}
Humans need the help of others in solving their life problems. Life problems always develop, along with the times. The problems faced by humans also change. This change provides a treatment from various parties, including da'wah as an alternative way to solve human problems. Da'wah with various elements has responsibility in solving human problems. Da'wah is carried out by various means, one of which is guidance and counseling, both of which are used as references in carrying out da'wah. Something that is needed now is to increase the role of da'wah with guidance and counseling, so as to be able to solve human problems. This article focuses on the elaboration of guidance and counseling in solving human problems within the framework of da'wah
\end{abstract}

Manusia memerlukan bantuan orang lain dalam menyelesaikan persoalan hidupnya. Persoalan kehidupan selalu berkembang, seiring dengan perkembangan zaman. Persoalan yang dihadapi manusia juga mengalami perubahan. Perubahan ini memberikan sebuah perlakuan dari berbagai pihak, termasuk dakwah sebagai alternatif jalan menyelesaikan masalah manusia. Dakwah dengan berbagai unsurnya mempunyai tanggungjawab dalam menyelesaikan persoalan manusia. Dakwah dilakukan dengan berbagai jalan, salah satunya adalah bimbingan dan konseling, Kedua hal ini dijadikan sebagai referensi dalam melaksanakan dakwah. Sesuatu yang dibutuhkan saat ini adalah meningkatkan peran dakwah dengan bimbingan dan konseling, sehingga mampu menyelesaikan masalah manusia. Artikel ini fokus pada elaborasi bimbingan dan konseling dalam menyelesaikan persoalan manusia dalam kerangka dakwah.

Kata Kunci: Dakwah Islam, Bimbingan dan Konseling 


\section{A. Latar belakang}

Realitas menunjukkan bahwa krisis ekonomi dan moneter yang sampai sekarang masih melanda negara kita ternyata telah memberikan ekses yang cukup serius bagi kita. Sendi-sendi ekonomi kita runtuh yang dimulai dengan melemahnya nilai tukar rupiah, sehingga aktifitas produksi dan arus perdagangan mengalami kelesuan dan dapat dikatakan hampir lumpuh total.

Keadaan seperti itu berdampak pada meluasnya pemutusan hubungan kerja (PHK) dengan klaryawan pabrik atau industri. Kebijakan PHK yang dilakukan oleh para pengusaha dimaksudkan untuk menyelamatkan usahanya, akan tetapi kebijakan tersebut merupakan pukulan berat bagi karyawan ter-PHK, walaupun bagi pengusaha juga merupakan suatu ujian berat baginya.

Dampak lain dari krisis ekonomi dan moneter ternyata tidak hanya dialami oleh para pelaku ekonomi dan pekerjaannya, tetapi juga sewmua lapisan masyarakat terutama bagi masyarakat yang berstrata sosial menengah kebawah. Mereka banyak mengalami goncangan psikologis. Hal ini disebabkan karena adanya kekhawatiran bahwa kesusahan-kesusahan hidup akan dialami oleh mereka. Ternyata, apa yang mereka khawatirkan benar-benar terjadi dan dialaminya. Terbukti dalam waktu singkat, krisis ekonomi dan moneter telah meningkat prosentase definitif tentang kehidupan dibawah garis kemiskinan.

Bila kemiskinan telah melanda tidak hanya cukup melibatkan satu aspek saja untuk menanganinya, seperti ekonomi misalnya. Sebagaimana dikemukakan oleh Soetomo bahwa pemahaman dan penanganan masalah kemiskinan tidak bisa tidak perlu melibatkan banyak aspek, terutama ekonomis, sosiologis, psikologis dan politis. Aspek ekonomis antara lain menyangkut terbatasnya pemilihan faktor produksi, rendahnya tingkat upah, posisi tawarmenawar yang lemah dalam menentukan harga, rentan terhadap kebutuhan mendesak karena tidak punya tabungan, kemampuan yang lemah dalam mengantisipasi peluang ekonomi. Aspek sosiologis terutama sosial, terbatasnya interaksi sosial dan terbatasnya penguasaan informasi. Aspek psikologis terutama berkaitan dengan perasaan rendah diri, sikap fatalisme, merasa terisolir. Aspek politis antara lain berkaitan dengan kecilnya akses terhadap berbagai fasilitas dan kesempatan, perlakuan diskriminatif, lemahnya posisi dalam melakukan bargaining untuk menuntut hak dan kurangnya keterlibatan dalam proses pengambilan keputusan. ${ }^{1}$

Kekurangsiapan seseorang dalam menghadapi suatu masalah secara mendadak seperti digambarkan di atas dapat menimbulkan masalah psikologis, seperti stres, rendah diri, pesimistis dan penyakit jiwa lainnya. Masalah-masalah kejiwaan seperti inilah yang akan dibahas dalam tulisan ini. Namun, perlu

1 Soetomo, Masalah Sosial dan Pembangunan, Jakarta: Pustaka Jaya, 1995, hlm. 121-122 
dikemukakan disini bahwa pendekatan yang digunakan untuk memecahkan masalah kejiwaan tersebut dengan menggunakan pendekatan bimbingan dan konseling yang bersumber pada nilai-nilai agama. Akan tetapi sebelumnya akan dikemukakan tentang sejarah singkat bimbingan dan konseling; pengertian dan ruang lingkupnya; dan fungsi; tugas; dan peranan bimbingan dan konseling.

\section{B. Sejarah Singkat Bimbingan dan Konseling}

Ditinjau dari sejarah perkembangan bimbingan dan konseling dapat kita ketahui bahwa tempat lahirnya ilmu pengetahuan ini adalah di negeri "Uncle Sam" yaitu Amerika Serikat. Pembinaan dan pengembangan secara ilmiah bimbingan dan konseling tersebut dimulai pada awal abad XX yang lalu, tepatnya pada tahun 1908 dimana waktu itu Fank Parson, salah seorang guru besar dan pengarang pada Universitas Boston mendirikan biro ketrampilan kerja (Vacation Bureau of Boston) dalam rangka program pusat pelayanan warga negara kota tersebut (The Civic Service House of Boston).

Frank Parson menulis sebuah buku yang berjudul " $A$ Choosing $a$ Vacation" berisi tentang pemikirannya yang bersifat mendasar dan menguraikan tentang berbagai metode pelatihan ketrampilan kerja disertai dengan contohcontoh kasus sederhana. ${ }^{2}$ Kemudian Frank Parson mendirikan suatu biro yang dimaksudkan untuk mencapai efisiensi kerja, dan beliaulah yang mengemukakan istilah atau pengertian tentang "Vacational Guidance", yang meliputi "Vocational Choice, Vocational Placement" dan "Vocational Training" yang diharapkan akan adanya efisiensi dalam lapangan pekerjaa. Dan dialah pula yang mengusulkan agar masalah "Vocational Guidance" dimasukkan dalam kurikulum sekolah.

Jesse B.Davis yang bertugas sebagai konselor sekolah di Central High School di Detroit, telah pula mulai bergerak dalam bidang ini, baik mengenai masalah-masalah yang ada pada tahun 1910-1916 dia memberikan kuliah-kuliah mengenai bimbingan dan penyuluhan. Kegiatan-kegiatan yang serupa dilakukannya oleh Eli Wever di New York, John Brewer di Universitas Harvard. Mereka ini dapat pula dipandang sebagai para perintis dalam lapangan bimbingan dan penyuluhan. Dan pada tahun 1913 didirikanlah suatu perhimpunan diantara para pembimbing itu.

Setelah perang dunia ke-2, bimbingan dan penyuluhan lebih menampakkan kemanfaatannya bagi masyarakat. Bimbingan dan penyuluhan banyak bergerak dalam lapangan ketentaraan, terutama untuk mengem,balikan para tentara yang baru datang dari medan pertempuran untuk kembali ke dalam masyarakat biasa.

2 M Arifin, M.Ed, Teori-teori Counseling Umum dan Agama, Jakarta: Golden Terayon Press, 
Dengan demikian, jelaslah bagi kita bahwa bimbingan dan penyuluhan yang kita dapati sekarang ini merupakan perkembangan lebih lanjut dari "vocational guidance" yang dirintis oleh Frank Person.3 Sesuai dengan perkembangan zaman yang menuntut adanya perubahan, maka bidang gerak bimbingan dan penyuluhan tidak hanya terbatas pada lingkungan kerja dan sekolah saja sesuai dengan sejarah keberadaannya. Akan tetapi bidang gerak bimbingan dan penyuluhan makin lama makin menjadi luas, seperti dalam lingkungan keluarga, biro ketentraman, biro sosial, keagamaan dan sebagainya. Semua aspek tersebut menjadi bidang garapan bimbingan dan konseling sebagai jembatan dalam menyelesaikan persoalan manusia. Untuk itu, menjadi penting memaksimalkan peran bimbingan dan konseling.

\section{Pengertian Bimbingan dan Konseling serta Ruang Lingkupnya}

Membicarakan pengertian bimbingan dan konseling secara terminologi tidak dapat dipisahkan antara keduanya. Hal ini disebabkan karena di dalam prakteknya keduanya saling berhubungandan isi mengisi satu sama lainnya. Bimbingan menyangkut konseling dan sebaliknya konseling menyangkut bimbingan.

Untuk lebih jelasnya akan penulis paparkan tentang pengertian diantara keduanya. Secara bahasa, istilah bimbingan merupakan terjemahan dari "gudance"dan istilah penyuluhan atau konseling terjemahan dari "counseling". Secara terminologis, menurut Aryatmi, bimbingan adalah pertolongan yang diberikan oleh seseorang yang telah diberikan (dengan pengetahuan, pemahaman ketrampilan-ketrampilan tertentu yang diperlukan dalam menolong) kepada orang lain yang memerlukan pertolongan. ${ }^{4}$

Sedangkan menurut Bimo Walgito bahwa bimbingan adalah bantuan atau pertolongan yang diberikan oleh individu atau sekumpulan individu-individu dalam menghindari atau mengatasi kesulitan-kesulitan di dalam kehidupannya, agar individu-individuatau sekumpulan individu-individuitu dapat mencapai kesejahteraan hidupnya. ${ }^{5}$

Adapun konseling atau penyuluhan menurut Rachman Natawidjaja dapat diartikan sebagai hubungan timbal balik antara dua orang individu di mana yang seorang ( yaitu penyuluh ) berusaha membantu yang lain (yaitu klien) untuk mencapai pengertian tentang dirinya sendiri dalam hubungannya dengan masalah-

\footnotetext{
3 Bimo Walgito, 1995, hlm 9-10

${ }_{4}^{4}$ Kartini Kartono, Bimbingan dan Dasar-dasr Pelaksanaannya: Teknik bimbingan Praktis , Jakarta, Rajawali, 1985

${ }^{5}$ Bimo Walgito, Bimbingan dan penyuluhan di Sekolah,, Yogyakarta, Andi Offset, 1995, HIm 4
} 
masalah yang dihadapinya pada saat ini dan mungkin yang akan dihadapi pada masa yang akan datang ${ }^{6}$

Sedang Bimo Walgito mendefinisikan konseling atau penyuluhan sebagai suatu bentuk bantuan yang diberikan kepada individu dalam memecahkan masalah kehidupannya dengan wawancara, dengan cara-cara yang sesuai dengan keadaan individu yang dihadapi untuk mencapai kesejahteraan hidupnya ${ }^{7} \quad$ Bila kita lihat secara teliti dari pengertian bimbingan dan konseling yang dikemukakan oleh para ahli diatas terdapat antara kesamaan diantara keduanya, disamping adanya sifat-sifat yang khas yang membedakannya. Hal ini dapat dikemukakan sebagai berikut :

1. Penyuluhan merupakan salah satu metode dari bimbingan. Dengan demikian maka pengertian bimbingan lebih luas dari pengertian penyuluhan. Karena itu penyuluhan merupakan "guidance"tetapi tidak semua bentuk "guidance" merupakan penyuluhan.

2. Pada penyuluhan telah adanya masalah yang tertentu, yaitu masalah yang dihadapi oleh klien. Sedangkan dalam bimbingan tidak demikian halnya. Pada bimbingan bersifat preventif atau pencegahan, sedangkan pada penyuluhan lebih bersifat kuratif atau korektif. Bimbingan dapat diberikan sekalipun tidak adanya suatu masalah Keadaan ini tidak berarti bahwa dalam bimbingan sama sekali tidak didapati segi kuratif, dan sebaliknya pada penyuluhan tidak adanya segi poreventif. Dalam penyuluhan kita dapati segi yang preventif pula dalam arti menjaga atau mencegah jangan sampai timbul masalah yang lebih mendalam.

3. Penyuluhan pada prinsipnya dijalankan secara individual, yaitu antara konselor dengan klien secara"face to face". Sedangkan pada bimbinagan tidak demikian halnya dimana bimbingan dijalankan secara "group" atau kelompok. ${ }^{8}$

Disamping pengertian, perbedaan dan persamaan tentang bimbingan dan konseling yang telah di lemukakan diatas, bahwa ini akan dikemukakan tentang ruang lingkup bimbingan dan konseling. Apabila ditinjau dari segi cara pendekatan persoalan, kita membedakan : segi preventif, segi kuratif / korektif dan segi perseveratif. Ditinjau dari segi pendekatan terhadap sasaran yang ingin dilayani, kita mengenal : bimbingan individual dan bimbingan kelompok. Berdasarkan lapangan persoalan yang dilayani, ada;

a. persoalan pribadi,emosional dan psikologis.

b. Persoalan studi /edukatif;yaitu segala persoalan yang langsung berpengaruh pada studi.

c. Persoalan pergaulan,sosial.

6 Rachman Natawidjaja, Pendekatan-pendekatan Dalam Penyuluhan Kelompok, Bandung, Diponegoro, 1987, Hlm 32.

7 Prof. Dr. Bimo Walgito, Ibid, Hlm 5

8 Prof. Dr. Bimo Walgito, Ibid, Hl;m 8 
d. Persoalan memilih jurusan studi, pemilihan lapangan kerja,pembinaan jabatan.

e. Persoalan perkembangan anak,dan lain-lain ${ }^{9}$

\section{Fungsi, Tugas dan Peranan Bimbingan dan Konseling}

Secara teoritis menurut M Arifin bimbingan dan konseling secara umum berfungsi sebagai fasilitatordan motifator"Client"dalam upaya mengatasi dan memecahkan problem kehidupan "Client"dengan kemampuan yang ada pada dirinya sendiri. Fungsi ini dapat dijabarkan dalam tugas tugas kegiatan yang bersifat preventif (pencegahan) terhadap segala macam gangguan mental, spiritual, dan environmental (lingkungan) yang menghambat, mengancan atau yang menantang proses perkenbangan hihup client. Juga dijabarkan dalam kegiatan pelayanan yang bersifat represif(kuratif atau penyembuhan) terhadap segala bentuk penyakit mental dan spiritual atau fisikal client dengan cara melakukan referal (peimpahan) kepada para ahlinya, misalnya ahli kedokteran jiwa (psychiater), ahlijiwa(psycholog) atau ahli kedokteran umum (dokter kese hatan), ahli psychotherapy, dan sebagainya.

Adapun tugas bimbingan dan konseling secara umum adalah memberikan pelayanan kepada klien agar supaya mampu mengaktifkan potensifisik dan psikisnyasendiri dalam menghadapi dan memecahkan kesulitankesulitan hidup yang dirasakan sebagai penghalang atau penghambat perkembangan lebih lanjut dalam bidang-bidang tertentu. ${ }^{10}$

Lebih lanjut M Arifin mengatakan bahwa dalan praktek antara fungsi dan tugasbimbingan dan konseling ini tidak dapat di bedakan atau dipisahkan sama sekali, oleh karena keduanya sama-sama terlibat dalam proses operasional bimbingan dan konseling yang terprogram. Sebenarnya tugas adalah penjabaran dari fungsi bimbingan dan konselingdalam rupa kegiatan pelayanan tersebut. ${ }^{11}$

Disamping fungsi dan tugas tersebut, bimbigan dan konseling memiliki peranan yang sangat penting dalam mengemban tugas kegiatan untuk membantu dan mengatasi masalah yang dihadapi oleh klien . namun peranan yang diemban oleh seorang pembimbing dan konselor haruslah disesuaikan dengan spesifikasi masalah yang dihadapi oleh klien. Oleh karena itu langkah utama yang harus dilakukan oleh seorang pembimbing dan konselor adalah mengidentifikasi masalah yang ada pada kliennya.

Bila hal di atas telah dilakukan oleh pembimbing dan konselor, maka akan dapat dicapai aktifitas bimbingandan konseling yang efektif. Aktifitas bimbingan dan konseling dapat dikatakan efektif apabila disamping mengetahui

\footnotetext{
${ }^{9}$ Aryatmi dalam Kartini Kartono, Ibid, Hlm. 13_- 14

10 Prif. H. M. Arifin, M. Ed, Ibid, HIm . 23

11 ibid ,hlm. 24.
} 
persoalan klien secara betul dan dapat mengidentifikannya secara baik, kunci utamanya terletak pada ketrampilan yang dimiliki oleh seorang pembimbing dan konselor.

Oleh karena itu, seorang pembimbing dan konselor haruslah memiliki bobot tertentu yang dapat memperlancar relasi bimbingan dan konseling, memiliki pengetahuan dasar menyangkut teori dan praktek bimbingan dan konseling, serta ketrampilan berwawancara dan intervensi dalam pemecahan masalah. Namun yang perlu diingat bahwa peranan utama pembimbing dan konselor hanya sebatas membantu klien bukan menyelesaikan masalahnya. Sebagaimana dikemukakan oleh Antony Yeo bahwa seorang pembimbing/konselor diharapkan mempunyai keahlian untuk membantu orang mengatasi masalah-masalah mereka dengan tekanan pada menolong dan bukannya menyelesaikan. ${ }^{12}$

\section{E. Bimbingan dan Konseling Sebagai Media Pendekatan Dakwah Islam}

Kehadiran islam yang dibawa oleh nabi kita Muhammad saw yang diutus oleh Allah SWT untuk menjadi rahmat seluruh alam merupakan agama yang mementingkan suatu kedamaian dan ketentraman. Disamping itu, Rasulullah saw juga diutus untuk menyempurnakan akhlak manusia. dalam sabdanya disebutkan "sesungguhnya aku (Muhammad) diutus untuk menyempurnakan akhlak yang mulia"

Berdasarkan atas hadis tersebut dapat dikatakan bahwa sebenarnya Nabi Muhammad saw merupakan konselor besar ditengah-tengah sahabatnya dan umat-umatnya sepanjang zaman. Penyempurna persoalan akhlak ini merupakan tugas Muhammad SAW atas dasar perintah Allah SWT. Muhammad mempunyai tugas dasar ini sebagai perwujudan untuk menyelesaikan persoalan yang dihadapi manusia di muka bumi ini.

Atas dasar pemikiran di atas, agama merupakan sumber yang dapat membantu memecahkan problem seseorang melalui potensi keimanannya. Dengan menggunakan pendekatan keagamaan dalam bimbingan dan konseling tersebut, klien dapat diberi insight (kesadaran terhadap adanya hubungan sebab-akibat dalam rangkaian problem-problem yang dialami) dalam pribadinya yang dihubungkan dengan nilai keimanannya yang mungkin pada saat itu sudah lenyap dari dalam jiwa klien.13 Melalui keimanannya itu diharapkan dapat membantu memecahkan masalah yang dihadapi oleh klien. Sebab semakin kuat iman seseorang akan semakin memberikan peluang menemukan jalan keluar yang terbaik baginya.

\footnotetext{
12 Antony Yeo,konseling Suatu Pendekatan Pemecahan Masalah,Jakarta BPK Gunung Mulia ,1994,hlm :60

${ }^{13}$ H.M.Arifin, ibid, hlm.20.
} 
Bimbingan dan konseling agama menurut Jung sebagaimana dikutip oleh Arifin dapat dilakukan dengan menerapkan psikoterapi berdasarkan pendekatan agama yang kemudian dikenal dengan Religio-Psichoterapy yaitu penyembuhan penyakit melalui kejiwaan yang didasarkan dengan nilai keagamaan. ${ }^{14}$ Religio psychoterapy dimaksudkan sebagai terapi psikologis yang berangkat dari nilai ajaran agama. Agama dalam hal ini Islam mempunyai peranan yang cukup tinggi sebagai sumber berlindung dan berteduh bagi orang yang sedang memerlukan pertolongan dari gangguan mental spirirual bahkan fisikal.

Seperti diterangkan di muka bahwa Nabi Muhammad sawsebagai seorang konnselor besar yang dapat menyejukkan hati bagi umatnya. Demikian pula ulama atau da'I kata Arifin dapat dikatakan sebagai seorang pembimbing dan penyuluh (konselor)agama yang tugasnya sebagaijuru penerang, pemberi petunjuk kejalan arah kebenaran juga sebagai juru pengingat (muzakkir) juru penghibur hati yang duka serta sebagai mubaligh (penyampai pesan-pesan agama)yang perilaku sehari-harinya mencerminkan sebagai uswatun hasanah (contoh teladan yang baik) di tengah umatnya.15

Dengan demikian bahwa seorang ulama atau da'i dapat dikatakan sebagai pembimbing dan konselor agama yang secara derektif disamping memberikan terapi juga dapat menyampaikan pesa-pesan agama sebagai tugas dakwah islam. Dakwah Islam dengan menggunakan media bimbingan dan konseling sangat tepat, karena antara konselor agama dan klien dapat bertemu dan bertukar pikiran secara langsung. Hal ini akan memberikan dampak positif bagi klien, karena dapat mengungkapkan segala macam masalah yang dihadapinya.

Namun yang perlu diingat bahwa bimbingan dan konseling sebenarnya tidak hanya diperuntukkan bagi orang yang baru mengatasi masalah serius atau dimanfaatkan pada saat orang menghadapi gangguan atau penyakit kejiwaan, akan tetapi lebih dari itu, yakni semua yang membuhkan bantuan psikologis. Demikian juga bimbigan dan konseling agama dituntut untuk dapat mengembangkan tugasnya disamping sebagai pembimbing dan konselor agama juga dapat berperan menumbuhkan kembali potensi keimanan yang dimiliki kliennya.

Oleh karena itu, bidang garap dan sasaran yang perlu diperhatikan terutama bagi konselor agama maupun konselor non-agama seperti yang dikemukakan oleh Shertzer dan Stone yang dikutip oleh W.S Winkel bahwa sejumlah kelompok orang yang biasanya membutuhkan bantuan psikologis melalui pelayanan bimbingan adalah mereka yang mencari pekerjaan dan dilayani melalui suatu biro penempatan tenaga (United States Employment Service).

Garapan USES adalah mereka yang cedera atau luka berat akibat pertempuran perang atau kecelakaan, dan dilayani melalui instansi-instansi

${ }^{14}$ Ibid,hlm.62

15 Ibid,hlm.30 
rehabilitasi (Vocational Rehabilitation Administration); mereka yang ditahan dalam lembaga-lembaga kemasyarakatan serta perlu dipersiapkan untuk kembali kemasyarakat, dan dilayani melalui layanan konseling individual dan konseling kelompok (Publik Offender Conseling).

Setelah mereka kembali dari medan pertempuran (para Veteran) dan harus kembali berpartisipasi dalam masyarakaat (Veterans Administration); banyak anggota masyarakat yang menghadapi problematik khusus, seperti alkoholisme, ketagihan obat bius, gangguan / penyakit serius, keretakan dalam keluarga, dan sebagainya (Cummanity Agencies); kelompok warga masyarakat yang sedang menghadapi suatu krisis dalam kehidupannya, seperti kehamilan di luar perkawinan, pemerkosaan, kehilangan pegangan akibat diputus hubungan kerja, masa pensiun dan sebagainya (Crisis Center; Biro Konsultan); semua orang yang berkonsultasi dengan seorang konseloryang membantu praktek privat (Privat Practice Counselors);

Garapan untuk kaum buruh yang bekerja diperusahaan dan pabrik (Bussiness and Industry Guidance); penderita yang sedang dirawat dirumah sakit dan mengidap penyakit serius (Hospital and Hospice Councelors) siswa-siswi di sekolah dan mahasiswa-mahasiswa di perguruan tinggi (Elementary Schol Guidance; Secondary Schol Guidance; Higher Education Guidance). Dari daftar ini ternyata bahwa pelayanan bimbingan dapat tersebar secara luas dalam masyarakat. $^{16}$

Luasnya bidang garap bimbingan dan konseling yang telah disebutkan di atas dapat di manfaatkan oleh konselor agama dalam mengemban misi dakwah Islam yang dapat di jadikan sebagai sasaran dakwah. Namun tampaknya institusi dakwah islam sampai saat ini belum memanfatkan peluang dan merambah pada sasaran yang menjadi bidang garap dan konseling secara komprehensif. Dikatakan belum komprehensif karena selama ini institusi dakwah islam yang membuka pelayanan bimbingan dan konseling hanya terbatas pada problematik keluarga. Dakwah islam belum merambah pada semua aspek persoalan manusia. Padahal hakekatnya semua aspek kehidupan ini dapat didekati oleh kajian bimbingan konseling.

\section{F. Kesimpulan dan Penutup}

Luasnya bidang garap bimbingan dan konseling yang telah disebutkan di atas dapat di manfaatkan oleh konselor agama dalam mengemban misi dakwah Islam yang dapat di jadikan sebagai sasaran dakwah. Namun tampaknya institusi dakwah islam sampai saat ini belum memanfatkan peluang dan merambah pada sasaran yang menjadi bidang garap dan konseling secara komprehensif. Dikatakan HIm . 77

16 W.S. Winkel, Bimbingan dan Konseling di Institut Pendidikan,Jakarta, Grasindo, 1997, 
belum komprehensif karena selama ini institusi dakwah islam yang membuka pelayanan bimbingan dan konseling hanya terbatas pada problematik keluarga. Dakwah islam belum merambah pada semua aspek persoalan manusia. Padahal hakekatnya semua aspek kehidupan ini dapat didekati oleh kajian bimbingan dan konseling. 


\section{Daftar Pustaka}

Yeo Anthony, Konseling: Suatu Pendekatan Pemecahan Masalah, Jakarta: BPK Gunung Mulia.

Walgito, Bimo, Bimbingan dam Penyuluhan di Sekolah, Yogyakarta: Andi Offset, 1995.

Kartono, Kartini, (Ed), Bimbingan dan Dasar-dasar Pelaksanaannya: Teknik Bimbingan Praktis, Jakarta: Rajawali, 1985.

Arifin, M., Teori-teori Counselng Umum dan Agama, Jakarta: Golden Terayon Press, 1984.

Natawidjaja, Rochman, Pendekatan-pendekatan Dalam Penyuluhan Kelompok, Bandung: Diponegoro, 1987.

Soetomo, Masalah Sosial dan Pembangunan, Jakarta: Pustaka Jaya, 1995.

Winkel, W.S, Bimbingan dan Konseling di Institut Pendidikan, Jakarta: Grasindo, 1997. 